\title{
СИБИРЬ ХУШ, СИБИРЬ ГАЦУУРЫН ТАРЬЦ УРГУУЛСАН СУДАЛГААНЫ ДУН
}

Ц.Дашзэвэг, С.Амартүвшин

ШУА-ийн Геоэкологийн хүрээлэн su.amartuvshin@yahoo.com

\section{ОРШИЛ}

Сибирь хуш (Pinus sibirica, Mayr.) нь Азийн бореальный бүсийн аж ахуйн өндөр үнэт модны нэг юм. Сибирь хушны байгалийн тархан ургалт зөвхөн Монгол улс, ОХУ, Казакстаны нутаг дэвсгэрт байдаг бөгөөд ойролцоогоор ОХУ-ын Сибирь, Урал, Алтайн хязгаар, Европын зүүн хойт хэсэгт 35 сая га, Казакстанд 0.04 сая га, Монгол улсын нутагт 1.0 сая га талбайд тус тус ургадаг. Сибирь хушны байгалийн тархалтын хойт хил Енисей мөрний татмаар дамжин хойт туйл хүрч, өмнөт хил нь Монгол улсын нутаг дэвсгэрт байх ба хойт өргөргийн $68^{\circ} 30^{\prime}$-аaс $46^{\circ} 30^{\prime}$-ын хооронд юм.

Манай орны умард хэсгийн ой бүхий талбай 13.8 сая га [10] байгаагийн 7.2\%-д хушин ой ургадаг. Хуш нь манай орны ой бүхий уул, нуруудын тунадас их унадаг, нилээд чийглэг, харьцангуй бага эрс тэс уур амьсгалтай газруудад алаг цоог тархалттай ургана. Хуш нь царам, царам-тайга, тайгын ойн бүслүүрт уулын хойт хажуугийн ихэвчлэн дээд хэсэгт, дангаар, эсвэл голдуу шинэстэй хамт ургаж ой үүсгэдэг.

Хушны үр (самар) нь өндөр чанартай, маш их калорлог хүнсний бүтээгдэхүүн ба $70 \%$ хүртэл тос агуулахын зэрэгцээ уураг, нүүрс ус, амин дэмүүдтэй. Хуш нь нарсны давирхайн гарцаас дутахгүй хэмжээний давирхай өгдөг мод юм. Хушны шилмүүсийг эмчилгээний бэлдмэлүүд хийхэд ашигладаг. Хушин ой их хэмжээний фитонцид ялгаруулах тул агаар орчныг ариутган цэвэршүүлнэ.

Сибирь гацуур (Picea obovata Ldb.) нь дангаараа болон модлог ургамлын ташингад зонхилон ургаж гацууран ойг үүсгэдэг мөнх ногоон шилмүүст мод юм. Гацууран ой дэлхийн бөмбөрцгийн хойт хагасын сэрүүн бүслүүрт тохиолдох ба Европ, Ази, хойт Америкийн ойн талбайн нилээд хэсгийг эзэлнэ. Европын зүүн хойт хэсгээс эхлээд Сибирь, Агнуурын тэнгис хүртлэх газарт, мөн Урал, Алтай, Саяны уулсаар жодоо, шинэс, нарс, хус, улиангар зэрэг модтой голдуу холилдон, хааяа цэвэр ой Үүсгэн ойролцоогоор 25 мянган га талбайд ургадаг. Ойн бүрэлдэхүүнд Сибирь гацуур давамгайлсан нилээд их хэмжээтэй ой Урал, баруун ба зүүн Сибирьт тохиолдоно.

Гацуурын төрөлд нийт 45 зүйл гацуур байдгаас манай оронд жинхэнэ гацуурын дэд төрөлд хамаарах Сибирь гацуур ургадаг. Манай оронд Сибирь гацуур нь голын хөндий, жижиг гол, горхи дагаж, ой үүсгэгч үндсэн төрлийн мододтой холилдон ургадаг. Гацууран ой, гацуур зонхилон ургасан ойн нийт талбай 31.92 мянган га юм. Энэ нь улсын ойгоор бүрхэгдсэн нийт талбайн (заган ой орохгүйгээр) ойролцоогоор $0.3 \%$ болно.

Гацуурын модлогийг барилга, целлюлоз-цаасны үйлдвэр, мужааны ажил болон мебель хийх, хөгжмийн зэмсэг бэлтгэх, төмөр замын дэр мод, түлш зэрэгт хэрэглэдэг. Ойрын хугацаанд огтлож ашиглах гацууран ойд мод шүүслэлт явуулж, давирхайн бүтээгдэхүүнүүд гаргаж авч болно. Гацуурын шилмүүснээс эфирийн тос, С витамин, холтосноос идээлэх бодис гаргаж авдаг. Шилмүүс, нарийн мөчрийг шилмүүсний гурил хийхэд ашигладаг. Гацуурыг хот цэцэрлэгжүүлэлт, хамгаалалтын ойн зурвасанд өргөн хэрэглэдэг. 
Манай оронд зарим жил ойн түймэр ихээхэн хэмжээний талбайд гарч, гацуур, хушин ойн байгалийн аясаар сэргэн ургах явцыг хязгаарлан, цаашид тэлж ургах боломжийг хааж, ойн бүрэлдэхүүнд эдгээр модны оролцоо үргэлж аажмаар багасч байна. Иймд гацуур, хушны тарьц ургуулах агротехникийг боловсруулах, тайгын ойн бүслүүрт гацуур, хушин ойг зориудаар сэргээн ургуулах арга хэмжээг авч хэрэгжүүлэх зайлшгүй шаардлага тулгарч байна.

\section{СУДАЛГААНЫ МАТЕРИАЛ БА АРГАЗУЙ}

Сибирь хушны тарьц ургуулах судалгааны ажлыг ОХУ-ын Сибирьт нилээд өргөн хүрээтэй явуулсан байдаг [1; 9]. Манай оронд хушны тарьц бойжуулах, хушин ойг зориудаар нөхөн ургуулах талаар эрдэм шинжилгээний судалгаа, ойн аж ахуйн практик үйл ажиллагааны баримт сэлт хомс юм. Харин Сибирь хушны тарьц ургуулах үндэслэлийг боловсруулсан байна [4].

Хушны тарьц ургуулсан энэ мод үржүүлгийн газрыг нарс, шинэсний тарьц ургуулах туршилт судалгааг явуулах зорилгоор сонгож авсан [6] бөгөөд тэнд гацуур, хушны тарьц ургуулахад мөн амжилттай үр дүнд хүрсэн юм.

Хушны үрийн тайван байдалд байх хугацаа урт, үрийг тарилтанд бэлтгэх арга нь нарийн, их ажиллагаатай, тарьсан үр, соёог мэрэгчид, шувууд ихээр идэж устгадаг учраас хушны суулгацын материалыг ургуулахад ихээхэн хүндрэлтэй байдаг. Бид туршилтанд хэрэглэсэн хушны үрийг 2002 оны 9-р сарын дунд үед Төв аймгийн Мөнгөнморьт сумын нутаг дахь Хэрлэн голын эх орчмын Бурхан Халдун уулын ойролцоох уулын хушин ойгоос бэлтгэв. Хушны үрийг тарилтанд бэлтгэхдээ хуурай хөрстэй, ус тогтохгүй товгор газарт, хөрс хөлдөхөөргүй гүнд буюу 1.5-1.6 м гүн нүх ухаж хийв. Агааржилтыг хангах зорилгоор нүхний ёроолд 10-15 см зузаан хайрга асгаж, дээр нь мөн энэ хэмжээний зузаан элс хийлээ. Хушны үрийг эзэлхүүний 1:3 хэмжээтэйгээр бага зэрэг чийгтэй элстэй хольж, уг холимогийг элс бүхий нүхний ёроолд хийж, нүхийг булах шороотой холилдуулахгүйн тулд дээр нь банз тавьж тусгаарлав. Дараа нь банзны дээр шороо хийж нүхийг дүүргэлээ. Энэ аргаар хавар тарих хугацаа хүртэл үрийг стратификацийн үед нь байлгав.

Хөрс боловсруулалтын ажлыг 2002 оны 5-р сарын эхний 10 хоногт ПН-3-35 анжисаар 35-40 см гүнд хийж, дараа нь хүрзээр бутлан хольж, ургамлын үндэс, чулуу зэрэг хог хаягдлыг түүж, цэвэрлэсэн юм. Үр тарих даланг 2003 онд бэлтгэхдээ, мөн хүрзээр гүн гишгэн сийрүүлж, хог ургамлын үндэс, үлдэгдлийг цэвэрлэв.

Үр тарих даланг 1.1-1.2 м өргөнтэйгөөр, газрын гадаргаас дээш дунджаар 3-5 см өндөр бэлтгэлээ. Далангийн уртын дагуу хоорондоо 12 см зайтай, тус бүр нь дунджаар 15 см өргөн 3 мөр гаргаж үр тарив. Далангийн өргөн талын 2 ирмэгээс үр тарих мөр хүртлэх зай тус бүр 20 см юм. Өөрөөр хэлбэл, тарилтын бүдүүвч: 20-1512-15-12-15-20 болно.

Хушин ойг үрээр тарьж ургуулахад тогтвортой сайн үр дүн өгөхгүй тул сайн зохион байгуулагдсан, зөв сонгож авсан мод үржүүлгийн газарт хушны тарьц ургуулж, ойжуулах ажлыг тарьцаар гүйцэтгэх нь зүйтэй. Тайгархаг болон тайгын ойн бүслүүрийн зааг орчимд, эсвэл тайгын ойн бүслүүрт, жилийн тунадасны дундаж хэмжээ 300-350 мм-ээс дээш унадаг газарт хушны тарьц ургуулах мод үржүүлгийн газрыг сонгож авах хэрэгтэй.

Монгол орны нөхцөлд гацуур нь чийгтэй, үржил шимтэй хөрстэй, температурын эрс тэс хэлбэлзэл, хөрсний хаталтаас хамгаалагдсан газарт ургадаг. Гацуурын тарьцыг үржил шимтэй, усны шүүрэлт сайтай хөрсөнд ургуулдаг. Хүнд хөрсөнд органик болон эрдэс бордоо хэрэглэнэ. Тарьц ургуулах 
талбайг сонгохдоо, хаврын хүйтнээс сайн хамгаалагдсан газарт авна.

Сибирь гацуурын үр тарих даланг 1.1 м өргөн, 10 м урттайгаар авч, газрын гадаргаас дээш дунджаар 3 см өндөр бэлтгэв. Далангийн уртын дагуу хоорондоо 12 см зайтай, тус бүр нь дунджаар 8 см өргөн 4 мөр гаргаж үр тарилаа. Далангийн хоёр талаас үр тарих мөр хүртлэх зай тус бүр 20 см юм. Өөрөөр хэлбэл, тарилтын бүдүүвч 20-8-12-8-12-8-12-8-20 болно.

Гацуурын үрийг зөвхөн хавар тарих ба үр тарьснаас хойш 20-25 хоногийн дараа буюу хаврын сүүлчийн хүйтрэлтийн дараа цухуйц гарч ирэхээр тооцоолж тарина. Өргөн туузан мөрөнд (5-6 эгнээ) тарьж, үрийг хөнгөн сэвсгэр материалаар хучина. Нэг уртааш метр мөрөнд 1.8 гр чанарын нэгдүгээр зэргийн үр орно. Зуны хугацаанд тарилт хийсэн далангийн хог ургамлыг устгах, хөрсийг сийрүүлэх, бордох, цухуйцыг сүүдэрлэх шаардлагатай. Тайгын бүслүүрийн сэрүүвтэр, хөрс муу халдаг газарт гацуурын цухуйц, тарьцыг хүйтрэлтээс хамгаалах зорилгоор газрын гадаргаас дээш өндөрсгөсөн даланд тарих хэрэгтэй. Гацуурын тарьцыг ойн бүс, бүслүүрийн ургах орчны нөхцлөөс хамааруулан 3-4 жил ургуулна. Мод үржүүлгийн газрын бойжуулах хэсэгт тарьцаас суулгац бойжуулах ажлыг 2-5 жил хийнэ.

ОХУ-д Сибирь гацуур, Европ гацуур хоёр дээр селекцийн ажил хийгдсэн байдаг. Сибирь гацуурын хэд хэдэн янз зүйлийг ялгасны хамт, уулархаг районы нөхцөлд “хөндийн” ба “өндөр уулын” гэсэн хэлбэрүүд байдаг. Эдгээр нь холтос, титэм, боргоцойн өнге зэргийн морфологийн хэлбэрүүдээр ялгагдана. Европын хэсгийн зүүн районуудад Сибирь гацуур, Европ гацуур хоёрын дундаас гарсан байгалийн эрлийз гацуур байх ба энэ нь нилээд өндөр бүтээмжтэй, орчны тохиромжгүй хүчин зүйлс, өвчин, хортонд тэсвэртэй юм. Эдгээр болон бусад зүйлүүдийн хоорондоос зориудын аргаар гетерозис эрлийзүүд гаргасан нь хурдан өсөлттэй, хүйтэн ба хуурайшилт, агаарын бохирдолтод харьцангуй их тэсвэртэй байх зэрэг эерэг шинж чанарууд нь хадгалагдсан байна [8].

Манай оронд хушин ойн болон гацуур оролцсон холимог ойн мод бэлтгэсэн, түймэрт шатсан газрыг аж ахуйн зориулалтаар ойжуулах, эдгээр модны тарьц, суулгац ургуулах агротехник, технологи байхгүй юм. Бид 2002 оноос эхлэн хуш, гацуурын тарьц, суулгац ургуулах судалгааг гүйцэтгэж ирсэн [3; 5] ба ойжуулалтанд хэрэглэх хуш, гацуурын тарьц, суулгацын өсөлт, хөгжилтийг (насыг) тогтоосон стандарт боловсруулав [2].

\section{СУДАЛГААНЫ ҮР ДҮН}

Сибирь хуш, Сибирь гацуурын тарьц ургуулах судалгааг 2002 оноос эхлэн Сэлэнгэ аймгийн Мандал сумын Түнхэл багийн нутаг болох Үнэглэгийн аманд (Түнхэл багаас хойш 15 км, төмөр замын 264-р өртөөнөөс 6 км) дахь ШУА-ийн Геоэкологийн хүрээлэнгийн туршилтын мод үржүүлгийн газарт явуулав. Энэ нутаг нь Монгол орны ой-ургамалжилтын ангиллаар Өмнөд Өвөр Байгалийн мужийн Баруун Хэнтийн хошууны Хараа-Шарын голын тойрогт хамаарна [11]. Тус тойрогт тайгын бүслүүрийн хуш, гацуур-хуш, шинэс-хушин ой, тайгархаг бүслүүрийн нарс, шинэс, хусан ой зонхилон ургадаг. Эдгээр бүслүүрийн ой нь далайн төвшнээс дээш дунджаар 13001700 м-т тархах ба уулын тайгын ширэгт, уулын цэвдэгт тайгын болон уулын ялзмагт сул чандруулаг хэвшинжийн хөрстэй [7].

Энэ нутаг дэвсгэр нь эрс тэс уур амьсгалтай, дулаан, чийгэрхэг, жилийн дундаж агаарын температур $-1.9^{\circ} \mathrm{C}$, жилийн тунадасны дундаж хэмжээ 265 мм юм. Энд $10^{\circ} \mathrm{C}$-ээс дээш байх жилийн дундаж температурын нийлбэр 1957 ( $\left.\sum \mathrm{T}\right)$, энэ хугацаанд унах тунадасны нийлбэр 216 мм $\left(\sum \mathrm{N}\right)$ ба ус-дулааны коэффициент $\left[\frac{\sum N}{\sum^{T}} \cdot 10\right]$ ойролцоогоор 1.1 байна.

Туршилтын мод үржүүлгийн газар 
нь тайгархаг ойн бүслүүрийн доод хэсэгт, хус, улиангаран ойн захад, уг амнаас урсах бургас, хус бүхий горхины эрэгт, далайн төвшнөөс дээш 1106 м өндөрт байрладаг. Мод үржүүлгийн газрын хөрс нь Хэнтийн мужийн ойт хээрийн бүсэд хамрагдах уулын нугын бүдүүн ялзмагт бараан хөрсний хэвшинжит ангилалд багтана.

Хөрсний үе давхрагын морфологи бичиглэл нь:

$\mathrm{A}_{1}$ 0-30 см - Ургамлын үндсээр элбэг, үрлэн бүтэцтэй, нягт, чийглэг, хар хүрэн өнгийн шавранцар хөрс;

АВ 30-45 см - Ургамлын үндсээр дунд зэрэг, үрлэн бүтэцтэй, нягт, чийглэг, хүрэн өнгийн шавранцар хөрс;

В 50-70 см - Ургамлын үндсээр бага, бөөмөн бүтэцтэй, нягт, чийглэг, цайвар хүрэн өнгийн шавранцар хөрс;

В 70-100 см - Ургамлын үндэс үгүй, бөөмөн бүтэцтэй, нягт, чийглэг, цайвар бор өнгийн шавранцар хөрс;

Үнэглэгийн аман дахь мод үржүүлгийн газраас зүүн тийш, уг амыг өгсөж 1.5 орчим км газарт, амнаас урсах горхины эргээс урагш 100 м орчим зайд, бургас, улиангар оролцсон, ганц нэг нарс бүхий хусан ойд хөрсний дээж авав.

ХУснэгт 1

Мод үржүҮлгийн газар ба түүний ойролщоох ойн хөрсний механик бүрэлдэхүүн,

агрохимийн ҮзУҮлэлтүҮд

\begin{tabular}{|c|c|c|c|c|c|c|c|c|c|c|c|c|}
\hline \multirow[b]{2}{*}{ 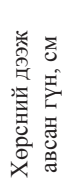 } & \multicolumn{11}{|c|}{ Хөрсний агрохимийн үзүүлэлтүүд болон механик бүрэлдэхүүн, \% } & \multirow[b]{2}{*}{ 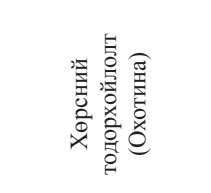 } \\
\hline & 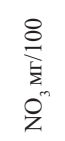 & $\begin{array}{l}\stackrel{8}{\circ} \\
\underset{\mid}{\mid} \\
0^{n} \\
0^{n}\end{array}$ & 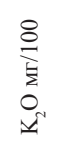 & 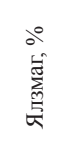 & $\begin{array}{l}n \\
0 \\
1 \\
0\end{array}$ & $\begin{array}{l}n \\
n \\
0 \\
1 \\
n \\
0\end{array}$ & $\begin{array}{l}\breve{1} \\
\stackrel{1}{1} \\
\text { ป̂ }\end{array}$ & $\begin{array}{l}n \\
0 \\
0 \\
1 \\
0 \\
0\end{array}$ & $\begin{array}{l}\overline{0} \\
0 \\
1 \\
1 \\
0 \\
0\end{array}$ & $\begin{array}{l}n \\
8 \\
0 \\
0 \\
1 \\
0 \\
0\end{array}$ & $\begin{array}{l} \\
8 \\
0 \\
1 \\
1 \\
0 \\
0 \\
0\end{array}$ & \\
\hline \multicolumn{13}{|c|}{ Ой дотор } \\
\hline $0-15$ & 4.00 & 2.75 & $>25$ & 10.06 & - & - & - & 30.9 & 46.1 & 8.7 & 14.3 & $\begin{array}{c}\text { Tоосорхог хөнгөн } \\
\text { шавранцар }\end{array}$ \\
\hline \multicolumn{13}{|c|}{ Мод үржүүлгийн газарт } \\
\hline $0-15$ & 3.50 & 2.55 & 18.0 & 8.70 & - & - & - & 15.0 & 63.6 & 9.5 & 11.9 & Тоосорхог элсэнцэр \\
\hline $15-30$ & 2.70 & 1.80 & 15.0 & 6.43 & 0.4 & - & - & 12.7 & 63.9 & 7.9 & 15.1 & $\begin{array}{c}\text { Тоосорхог хөнгөн } \\
\text { шавранцар }\end{array}$ \\
\hline $30-45$ & 1.50 & 1.39 & 12.0 & - & 0.3 & - & - & 9.2 & 57.2 & 8.7 & 24.6 & $\begin{array}{c}\text { Тоосорхог хүнд } \\
\text { шавранцар }\end{array}$ \\
\hline $45-60$ & - & - & - & - & - & 0.3 & - & 24.5 & 40.8 & 9.0 & 25.4 & $\begin{array}{c}\text { Тоосорхог хүнд } \\
\text { шавранцар }\end{array}$ \\
\hline $60-75$ & - & - & - & - & - & 0.3 & 0.3 & 18.9 & 43.9 & 13.8 & 22.8 & $\begin{array}{c}\text { Тоосорхог дунд } \\
\text { шавранцар }\end{array}$ \\
\hline
\end{tabular}

Мод үржүүлгийн газар болон ойн хөрсний аль аль нь А үе давхрагадаа ерөнхийдөө ижил шинж чанартай, хөнгөн шавранцар болон тоосорхог элсэнцэр механик бүрэлдэхүүнтэй, 100 гр хөрсөнд агуулагдах шим тэжээлийн элементүүдийн хэмжээг авч үзвэл, азот $\left(\mathrm{N}-\mathrm{NO}_{3}\right)$, хөдөлгөөнт фосфор ( $\left(\mathrm{P}_{2} \mathrm{O}_{5}\right)$, калийн $\left(\mathrm{K}-\mathrm{K}_{2} \mathrm{O}\right)$ хангамж сайн, ялзмагийн агууламжаар өндөр, хөрсний уусмалын орчин сул хүчиллэг ( $\mathrm{pH}=6.78-7.08)$, хөрсний чанар сайн байна (1 дүгээр хүснэгт).
Сибирь хушны үрийг намраас эхлэн өвлийн туршид стратификацилан, тарихын өмнө 2 хоног 0.05 хувийн марганецын уусмалд дэвтээж, 2003 оны 5-р сарын 23-нд тарив. Хушны үр тарьсан гүн 4 см ба нэг уртааш метр мөрөнд 400 ширхэг үр (самар) тарилаа. Үр тарих мөрийг далангийн гадаргаас доош 4 см гүн гаргаж, үрийг мөрүүдэд жигд тараан байрлуулсны дараа далангийн гадаргатай тэнцүу хэмжээнд хүртэл модны үртсээр хучив. Үр тарьсан өдрөөс эхлээд анхны цухуйцууд гарч ирэх 
хугацаа болон энэ хугацаатай үндсэндээ давхцсан зуны бороотой үе эхлэх хүртэл далангийн хөрсний өнгөн үе, үр тарьсан гүний хэмжээнд байнга чийгтэй байлгахаар тооцож, усалгаа тогтмол хийж байв. 2-3 дахь вегетацын хугацаанд, ялангуяа эхний хагаст, хөрсний чийгийн байдлыг харгалзан, шаардлагатай үед усалгаа хийлээ.

Хушны анхны цухуйцууд 6-р сарын сүүлийн хоногуудад гарч, 7-p сарын эхний 10 хоногт бараг бүрэн жигдэрч ургалаа. Тарьсан үр, соёог шувууд идэхээс хамгаалахын тулд анхны цухуйц гарахаас өмнө далангийн хөрсний гадаргаас 20-30 см өндөрт, дранк модоор хийсэн сүүдрэвч тавив. Хушны тарьц ургуулах туршилтыг том хэмжээний талбайд, олон даланд хийгээгүй тул шувууд, мэрэгчид идэж устгаагүй болно.

Тарьснаас хойш 3 дахь жилийн намар буюу хушны 3 настай тарьц нэг уртааш метр мөрөнд дунджаар 221 ширхэг ургасан байна. Хушны тарьц ургуулсан хугацааны эхний хоёр жилийн өвөлжилт, 3 вегетацийн хугацаанд тарьцын хорогдол маш бага явагдсан ба тарьцын нийт тооны 10\%-д хүрээгүй юм.

Хушны 3 настай тарьцын дундаж өндөр 8.5 см, хамгийн их өндөр $12.0 \mathrm{~cm}$, сүүлийн жилийн өндрийн дундаж өсөлт 4.3 см, хамгийн их нь 7.2 см байна. Тарьцын өсөлт зогсож, оройн нахиа зангидсны дараа 100 ширхэг дээж тарьц авч, газрын доод, дээд хэсгийн үнэмлэхүй хуурай жингийн харьцааг тодорхойлоход 0.5 байна. Хушны 100 ширхэг тарьцын газрын доод хэсгийн жин 34.7 гр, газрын дээд хэсгийн жин 68.7 гр юм (2 дугаар хүснэгт).

Үрийг тарихын өмнө 0.05 хувийн марганецын уусмалд хоёр хоног дэвтээж тарилаа. Гацуурын үрийг Оросын холбооны улсын Красноярск хот орчмын ойгоос 2001 онд түүж бэлтгэсэн байна. Үрийн техникийн соёололт $80.3 \%$, долоо хоногоор авсан үрийн ургах эрчим $24.0 \%$, мянган үрийн жин 5.4 гр зэрэг үзүүлэлт бүхий чанарын I-p зэргийн үр юм. Гацуурын үрийг 8 см өргөн мөрийн нэг уртааш метрт 8.0 гр орцтойгоор, 5-р сарын 28-нд тарив. Үр тарьсан гүн 1.0 см ба тарилтын дараа үр тарьсан мөрийг модны үртэсээр хучив. Хөрсөнд үр байрлах гүнээс доош 2-5 см үе давхрага байнга чийгтэй байхаар тооцоолж, өглөө, оройн цагт бороожуулан услаж байв.

Үр тарьсан өдрөөс хойш 15 хоногийн дараа буюу 6 сарын 11-нд гацуурын анхны цухуйцууд соёолон гарав. Цухуйцууд харьцангуй богино хугацаанд жигдрэн ургасан буюу 7 сарын эхний 10 хоногт нэг уртааш метр мөрөнд 790 ширхэг цухуйц ургалаа. Гацуурын нэг настай тарьцын намрын тооллогын дүнгээс үзэхэд, 1 уртааш метр мөрөнд дундажаар 720 ширхэг ургаж, бараг бүх тарьцын оройн нахиа зангидаж өвөлжилтийн бэлтгэлд орсон байна.

Эхний өвөлжилтийн дараах байдлаар буюу 2003 оны хаврын тооллогын дүнг, 2002 оны намрын тооллогын дүнтэй харьцуулж үзэхэд, гацуурын тарьцын $39.8 \%$ нь хорогдсон байлаa. 2003 оны ургамал ургалтын хугацаанд 2 настай тарьцын хорогдол харьцангуй бага явагдаж, тарьцын тооны 8\% нь хамрагдсан ба 2 настай тарьцын намрын тооллогын дүнг 1 настай үеийн намрын тооллогын дүнтэй харьцуулж үзэхэд, 1 уртааш метр мөрөн дэх гацуурын 2 настай тарьцын дундаж тоо 376 ширхэг буюу 52.2\%-ийн амьдралттай байв. Цаашид 3 ба 4 настай үедээ гацуурын тарьцын хорогдол нэг уртааш метр мөрөнд дунджаар 1-2\%-иас хэтрээгүй болно.

Тухайн ургах орчны нөхцөлд гацуурын 3 настай бүх тарьц 10 см-ээс намхан байгаа ба 4 настай үедээ нийт тарьцны тооны $70 \%$ орчим нь 10 см-ээс өндөр, 77\% нь 8.120.0 см-ийн хооронд байгаа өндөртэйгээр ургажээ (1 дугаар зураг). Энэ нь 3 настай үедээ харьцангуй жигд өндөртэй байснаа, 4 дэх вегетацийн хугацаанд өндрийн өсөлт сайн өгч, өндрөөрөө нилээд ялгаатай болсон нь харагдаж байна. Гацуурын 4 настай тарьцын дундаж өндөр 11.4 см, хамгийн дээд өндөр 21.5 см, сүүлийн жилийн өндрийн дундаж өсөлт $6.3 \mathrm{~cm}$, хамгийн 
их нь 14.1 см (2 дугаар хүснэгт) байна. Гацуурын 4 настай 100 ширхэг тарьцын үнэмлэхүй хуурай жинг тодорхойлоход, тарьцын газрын доод хэсгийн жин 31.1 гр, газрын дээд хэсгийн жин 62.7 гр байлаа.

“Шилмүүст төрлийн модны суулгац, техникийн шаардлага” нэртэй Монгол улсын стандарт (MNS-6139; 2010)-д зааснаас үзэхэд, гацуурын 4 настай 1-р зэргийн тарьцын өндөр 12 см-ээс дээш, үндэсний хүзүүний бүдүүн 3.0 мм-ээс дээш, үндэсний урт 22-30 см; 2-р зэргийн тарьцны өндөр 8-12 см, үндэсний хүзүүний бүдүүн 2.8-3.0 мм, үндэсний урт 15-21 см байна [2].

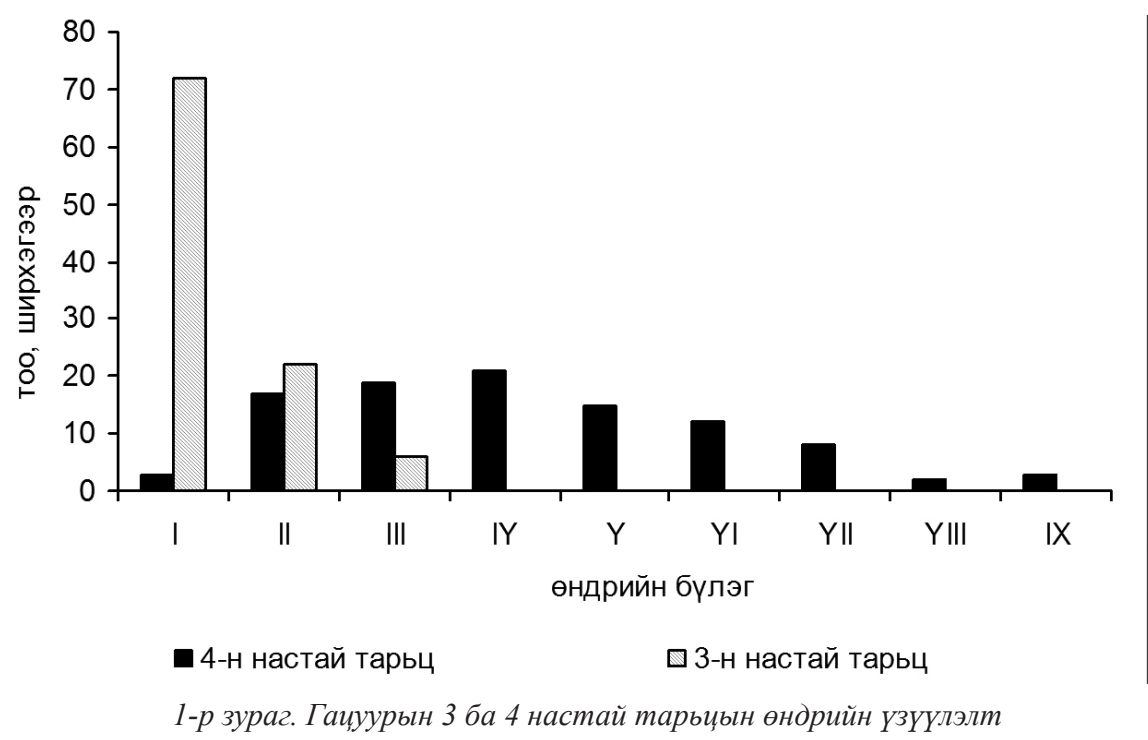

Бидний тарьж ургуулсан гацуурын 3 настай тарьц өндрийн хувьд бүгд 2-р зэрэглэлд хамарч, бусад үзүүлэлт ямар нэг хэмжээгээр шаардлагад нийцэж байгаа боловч, цаашид гацуурын тарьцыг ургах орчны өөр өөр нөхцөлд тарьж турших, стандартын зарим үзүүлэлтийг нарийвчлан тогтоох шаардлагатай нь харагдаж байна.

Газрын дээд, доод хэсгүүдийн өсөлт хөгжилтийн хэмжээ зохицсон, жингийн хэвийн харьцаатай, сайн чанарын суулгацын материалыг ойжуулалтын ажилд ашиглах шаардлагатай байдаг. Фотосинтезийн эрчимтэй үйл явц үндэсний өсөлтийг сайжруулснаар газрын дээд хэсгийн фитомассын өсөлтийг нэмэгдүүлэх замаар тарьц, суулгацын сорох үндэсүүд болон шилмүүсүүдийн амьдрал үйл ажиллагааны явц харилцан бие биедээ дэмжлэг өгөх байдал ажиглагддаг.
Сайн чанарын суулгацын материалыг мод үржүүлгийн газрын үрийн болон бойжуулах хэсэг дэх биоэкосистемийн тогтвортой нөхцлийг хангасан орчинзүйн зөвхөн хэвийн нөхцөлд ургуулж авч болно. Модны тарьц, суулгац нь гадаад орчны нөхцлийн өөрчлөлтийг маш соргогоор хүлээн авч өөрийгөө зохицуулдаг биологийн систем юм. Гадаад орчны тааламжгүй нөхцөл тарьц, суулгацын хэсгүҮдийн ерөнхий өсөлтийг бууруулж, хэвийн бус өсөлт хөгжилт өгөхөд хүргэдэг. Ийм суулгацын материалыг ойжуулалтад шилжүүлэхэд тэдгээрийн амьдралт доогуур байх ба суулгасны дараах эхний жилүүдэд өсөлт султай байна. Өөрөөр хэлбэл, тарьц, суулгацын нөөц бодис, шинээр үүсч байгаа шим тэжээлийн бодис нь үндэсний системийг нөхөн ургуулахын зэрэгцээ, өсөлтөөр хоцорсон эрхтэн, хэсгүүдийн 
өсөлтий $\quad$ хангахад зарцуулагдана. Суулгацын материалын эрхтэн, хэсгүүдийн өсөлтийн харьцаа хэдий чинээ их байхад, мод үржүүлгийн газарт ургах үедээ өсөлтөөр хоцорсон эрхтэн, хэсгүҮдийн өсөлтийг хангах явцад шаардагдах нөхөн сэлбэх бодисууд төдий чинээ их хэрэглэгдэнэ.

ХУснэгт 2

Сибирь хушны 3 настай, Сибирь гаиуурын 4 настай тарьцын өсөлтийн тоон ба чанарын ҮзУҮлэлтүҮд

\begin{tabular}{|c|c|c|c|c|c|c|c|c|c|c|c|}
\hline \multirow[b]{2}{*}{$\begin{array}{c}\text { Модны } \\
\text { төрөл }\end{array}$} & \multicolumn{2}{|c|}{$\begin{array}{l}\text { Тарьцын } \\
\text { өндөр, см }\end{array}$} & \multicolumn{2}{|c|}{$\begin{array}{l}\text { Сүүлийн жилийн } \\
\text { өндрийн өсөлт, см }\end{array}$} & \multirow{2}{*}{ 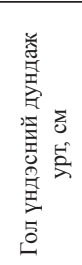 } & \multirow{2}{*}{ 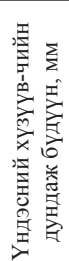 } & \multicolumn{4}{|c|}{$\begin{array}{c}100 \text { ширхэг тарьцын үнэмлэхүй } \\
\text { хуурай жин, гр }\end{array}$} & \multirow{2}{*}{ 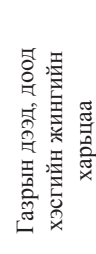 } \\
\hline & $\begin{array}{l}\text { 憲 } \\
\text { 焉 }\end{array}$ & 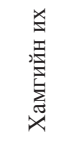 & 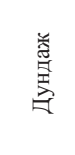 & 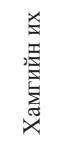 & & & 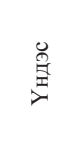 & $\begin{array}{l}\text { 这 } \\
\text { 晩 }\end{array}$ & 慁 & 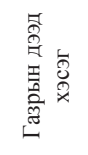 & \\
\hline Хуш & 8.55 & 12.0 & 4.31 & 7.2 & 23.69 & 2.87 & 34.68 & 46.74 & 21.97 & 68.71 & 0.5 \\
\hline Гацуур & 11.38 & 21.5 & 6.33 & 14.1 & 27.94 & 2.32 & 31.11 & 34.55 & 28.19 & 62.74 & 0.5 \\
\hline
\end{tabular}

Эрхтэн, хэсгүүдийн хөгжлийн хэвийн бус харьцаа нь шилмүүс, иш, үндсэн дэх тэжээлийн нөөц бодисуудын хэмжээг илэрхийлэх ургамлын эрхтэн, хэсгүүдийн фитомассын үзүүлэлтээр тогтоогдог. Эдгээр шим тэжээлийн нөөц бодис нь тарьцыг ухаж авах үед гэмтсэн үндэсний систем нөхөн сэргэхэд зарцуулагдах ба мөн газрын дээд хэсгийн эрхтнүүдийн ургалтад хэрэглэгдэнэ. Иймээс газрын дээд хэсгийн фитомасс хэдий чинээ их байх тусам, шим тэжээлийн бодис түүний өсөлтөд төдий чинээ их зарцуулагдаж, харин үндэсний системийн нөхөн ургалт удааширснаас ойжуулалтад шилжүүлсэн суулгацын амьдралт, өсөлт буурдаг. ИйнхүҮ эрхтэн, хэсгүүдийн өсөлт хөгжилтийн хэвийн харьцаатай суулгацын материалыг ойжуулалтад ашиглах нь суулгацын хэвийн өсөлт, амьдралтын нөхцлийг хангах үндэс болдог.

Гацуурын 4 настай тарьц, хушны 3 настай тарьцын газрын дээд, доод хэсгүүдийн шугаман өсөлт, фитомассын хэмжээг тодорхойлон үзэхэд, үндэсний жинг газрын дээд хэсгийн жинд харьцуулсан харьцаа энэ хоёр төрлийн модны тарьцан дээр адилхан 0.5 байна (2 дугаар хүснэгт). Гацуурын 3 ба 4 настай тарьцын эрхтэн, хэсгүүдийн шугаман өсөлт, фитомассын хэмжээг тодорхойлсон үзүүлэлтүүдээс харахад, гацуурын тарьцыг 3 настай үед нь ойжуулалтад шилжүүлэхэд, бусад насны тарьцыг шилжүүлснээс өсөлт хөгжилт, амьдралт дээгүүр байх, түүгээр зогсохгүй шилжүүлсэн тэр жилдээ өндрийн өсөлт өгөх бүрэн боломжтой байна (1 дүгээр зураг).

\section{ДҮГНЭЛТ}

Ой ургамалжилтын баруун Хэнтийн хошууны нөхцөлд Сибирь гацуурын тарьц ургуулахад үрийг хавар 5-р сарын 25-наас 6-р сарын 5-ны хооронд тарих нь тохиромжтой. Тарьц ургуулах даланг газрын гадаргаaс дээш 3-10 см өндөр бэлтгэж, үр тарих мөрүүдийн өргөнг 8 смээс хэтрүүлэхгүйгээр авах ба мөр хоорондын зай 12-15 см, үр тарих гүн 1.0-1.2 см байна. Үрийг модны үртэс зэрэг хөнгөн, сэвсгэр материалаар хучина. Гацуурын цухуйц хамгийн олон тоогоор ургасан үеэс буюу 7-р сарын эхнээс эхлэн 8-р сарын дунд үе хүртэл сүүдрэвч тавих шаардлагатай.

Мод үржүүлгийн газарт хушны үрийг хавар 5-р сарын сүүлийн 10 хоногт тарихад хамгийн тохиромжтой хугацаа юм. Үрийг тарилтанд бэлтгэхдээ, өмнөх жилийнх нь намар “удаан хугацааны траншейнд бэлтгэх” 
аргаар гүйцэтгэнэ. Үр тарих мөр хоорондын зайг 12-15 см-ээс бууруулахгүйгээр 8-10 см өргөн мөрөнд тарих ба чийг ихтэй нөхцөлд үр тарих даланг газрын гадаргын төвшингөөс 3-10 см өндөр байлгана. Тарих үрийн тохиромжтой норм 1 уртааш метр өргөн мөрөнд 400 ширхэг (ойролцоогоор 100 гр) 1-р зэргийн, бүрэн идээтэй үр орно. Бидний туршилтанд үр тарих хамгийн тохиромжтой гүн 4 см байв. Хөнгөн механик бүтэцтэй хөрсөнд үр тарих гүн 5-6 см байх нь Зүйтэй.

Сибирь гацуурын 3-4 настай, Сибирь хушны 4 настай тарьцыг ойжуулалтанд хэрэглэвэл зохино. Сибирь гацуурын 3-4 настай тарьцыг мод үржүүлгийн газрын бойжуулах хэсэгт 2-4 болон түүнээс дээш жил (8-10 жил) ургуулсны дараа хот цэцэрлэгжүүлэлт, хамгаалалтын ойн зурвас, ойжуулалтанд шилжүүлэн суулгах шаардлагатай.

\section{Ашигласан бүтээлийн жагсаалт}

[1]. Гуляев М.П. Из опыта выращивания кедра сибирского в лесном питомнике. -Труды по лесному хозяйству Сибири, вып.6, “Проблемы кедра”, Новосибирск, 1960.

[2]. Дашзэвэг Ц. Шилмүүст төрлийн модны суулгац, MNS-6139; 2010, - “Ойн ажлын стандарт”, Засгийн газрын хэрэгжүүлэгч агентлаг, Ойн газар, УБ, 2012, х, 107-115.

[3]. Дашзэвэг Ц., Амартүвшин. Сибирь гацуурын тарьц ургуулах судалгааны дүнгээс. Монгол орны геоэкологийн асуудал, №06, УБ, 2006, х.107-118.

[4]. Дашзэвэг Ц., Энхсайхан Д. Сибирь хуш тарьж ургуулах судалгааны тоймоос. -“Монгол орны ой үүсгэгч голлох төрлийн модны тарьц ургуулах, ойжуулах зөвлөмж” товхимолд, УБ, 1996, х.45-49.

[5]. Дашзэвэг Ц., Амартүвшин С., Баяржавхлан Н. Сибирь хушин ойн тархалт ба Монгол орны ой-ургамалжилтын Баруун Хэнтийн хошуунд Сибирь хушны тарьц ургуулсан судалгааны дүн.-ШУА-ийн Геоэкологийн хүр.эрд.шин.бүтээл, №05, УБ, 2005, х.43-51.

[6]. Дашзэвэг Ц., Амартүвшин С., Бат-Амгалан Р., Өсөхбаяр Б., Удвал Б. Баруун Хэнтийн нөхцөлд нарс, шинэсний тарьц ургуулах судалгааны зарим дүн.-ШУА-ийн Геоэкологийн хүр.эрд.шин.бүтээл, №04, АББЗСҮ төвийн хэвлэх үйлдвэр, УБ, 2004, х.277-283.

[7]. Леса Монгольской Народной Республики (география и типология). М.:Наука, 1978, $-127 \mathrm{c}$.

[8]. Лесная энциклопедия, том I.-М., “Советская энциклопедия”, 1985, х.305-312.

[9]. Лоскутов Р.И. Искусственное восстановление кедра Сибирского. Изд. “Лесн. пром-сть”, М. 1971, -105c.

[10]. Нарангэрэл 3. Ойн сангийн судалгааны ажлын үр дүнгээс. -“Монгол орны ойг ашиглах, хамгаалах, нөхөн сэргээх асуудлууд" номонд, Байгаль, Ой, Усны нөөцийн газар, Геоэкологийн хүрээлэн, “Мөнхийн үсэг” ХК-ийн хэвлэх үйлдвэр, УБ, 2004, х.184-188.

[11].Цэдэндаш Г. Умард Монголын ой-ургамалжилтын мужлалын асуудалд. -Ой, ан судлалын хүрээлэнгийн эрдэм шинжилгээний бүтээл, №2, УБ, 1996, х 24-29. 


\title{
SOME RESULTS OF EXPERIMENT TO RAISE SEEDLING OF PINUS SIBIRICA MAYR. AND PICEA OBOVATA LDB.
}

\author{
Ts.Dashzeveg, S.Amartuvshin \\ Institute of Geoecology, MAS
}

In Mongolia, Picea obovata Ldb. grows along the river basin and stream line in mixture with main species of trees. The area of forest dominated by Picea obovata Ldb. is 31.92 thousand hectare in total, which equals to $0.3 \%$ of total forest of the country (excluding Saxsaul forest).

Experiment to raise Picea obovata seedling has been conducted in forest-vegetational zone of Western Khentii, first time in Mongolia. Experiment found that the most suitable period Picea obovata seeds are between 25 May and 5 June. This paper also presents agro-technique of raising Picea obovata Ldb. seedlings, linear parameters of above and below ground parts of seedling and biomass.

Distribution of Siberian Pine forests (Pinus sibirica, Mayr.), basic characteristics, types and present status of Siberian Pine forests of Mongolia are been given in detail. Research of raising seedlings of Siberian Pine was conducted in Tunkhel area of Mandal soum, Selenge aimag, 2003 onwards, and the agrotechnique of raising seedlings of Siberian Pine is been determined. 